\title{
Local Government Service Delivery in Nigeria: An Empirical Comparison of Government Efforts and the People's Expectations
}

\author{
Achimugu, Hassan \\ Department of Public Administration, Kogi State University, Anyigba- Nigeria \\ 08038132529. hassanachimugu@gmail.com \\ Stephen, Makoji Roberts \\ Salford University Business School, Greater Manchester, Uk \\ makaytovia@yahoo.com \\ Agboni, Uyo Joy \\ Department of Public Administration, Kogi State University, Anyigba- Nigeria
}

\section{Doi:10.5901/mjss.2013.v4n6p335}

\section{Abstract}

The under- performance of Nigeria's 776 Local governments have continued to attract huge policy and research concerns in the last three decades. This, among other reasons is because huge amount of resources is committed to this vital tier of government annually from the federation account, with very little visible impact on the lives of the nation's teaming rural population. This paper focuses on Ofu Local government in Kogi State - North Central -Nigeria. It evaluates how the local government has performed with regards to its internal workings and service delivery. The findings show that Ofu local government's performance by all indices does not justify the financial resources it has received from the federation account in the period under evaluation. The reasons for this under performance ranges from corruption to slow and inefficient administrative processes but most important is the fact that the peoples input is left out in policy designs. Hence government interventions are significantly at variance with the people's felt - need. The paper recommends among others, a bridge of gap driven by the active involvement of the people at all stages of programmes designed to offer them services.

Keywords: Local government, Service delivery, Local government performance, Local government Reforms, People's expectations

\section{Introduction}

Nigeria is a federation of 36 states grouped under six geo-political zones, with 774 local government areas, a population estimated at 148 million (World Bank Report, 2009). A land mass of about 923,768 square kilometres, huge oil and gas reserves as well as commercial deposits of solid minerals of international demands. These potentials notwithstanding, about $70 \%$ of the population are classified as poor while about $54.4 \%$, are absolutely poor and live below the global US\$1 benchmark, with life expectancy flirting between 48 and 52 years. These less than desirable indicators suggest a huge performance lapse on the side of government at all levels; but then, since about $70 \%$ of the population live in the rural areas (Ifinedo 2008), the local governments have huge responsibilities to bring development closer to the people and by implication engender the much needed socio-economic turn around Nigeria desires. Nigerian local governments are however known to be symbols of non performance, corruption, slow administrative processes, incompetent workforce, lack of/resistance to innovations etc (Iheme,2003).

Since the mid - sixties, Nigeria as a nation has continued to wade through very challenging circumstances and agitations that suggest public frustration and total loss of confidence in government's capacity to deliver public goods. Many years down the line after independence, the "all other things" (better society) that the political kingdom (Nigeria) of their dreams was supposed to bring, is still very well out of sight.

Government at the federal, state and local levels seem to have a number of things in common although in varying degrees. Corruption, the lack of transparency and accountability, wasteful practices that undermine the principles of cost - effectiveness, excessive bureaucracy - snail speed' administrative practices over-bloated workforce an almost 
impossible information retrieval system, generally weak infrastructures etc have become the public face of Nigeria public administration. As nauseating as this situation may seem, (Iheme,2003; BBC News, 2005; CIA-World Fact book, 2005) are of the opinion that Nigerian local governments bear the larger weight of governmental sluggishness, corruption and general lack of performance. This tilt has very far reaching implications because this level of government is directly responsible to a whopping $70 \%$ of the Nigerian population and as long as duties/responsibilities, within its (the local government's) constitutional mandate is not performed adequately, actual and sustainable national development would remain a mirage.

Ofu local government which is the focus of this study is administratively divided into six departments with both political and administrative heads and a number of civil servants in the employ of the local government. This notwithstanding, administrative processes are observably very slow and quite inefficient; information retrieval is very cumbersome, if not impossible and so actions on such data is delayed, internally generated revenue is simply laughable. The implication of these administrative lapses are that, the constitutional mandate of the local government is left undelivered thereby deepening poverty and exacerbating public outcry and loss of confidence in government, with its attendant consequences. The situation becomes even more disturbing, when placed side- by -side the huge financial receipts it gets from the Federation Account. The Ofu Local Government Legislative Council puts the figure at over 1.2 billion naira, in 2010.

\section{Conceptual issues}

\subsection{Local Government}

Akindele and Adeyemo (1997) while trying to arrive at a definite theory of Local Government examined some theoretical efforts already documented within the parameters of Local Government studies are relates to the functional and institutional relevance of Local Governments in the politics of the world especially in Nigeria. They reviewed the works of such scholars like Ola (1984) and Gboyega (1987) and noted that the first class attempts to justify the existence or need for local government on the basis of its being essential to a democratic regime or for practical administrative purposes like responsiveness, accountability and control. The other class of theories is contrapuntal to the first class of theories. This is in the sense that it argues that an effective Local Government system contradicts the purposes of a democratic regime. Conclusively, all the positions summed to three schools of thought:

(a) Democratic - participatory school

(b) The efficiency - service school

(c) The developmental school.

One could see that none of the three schools of thought is irrelevant to performance. Theoretically speaking therefore, Local Government is expected to enhance achievement of democratic ideals, political participation, protective services and infrastructural services like provision and maintenance of health facilities and intuitions. To this end, one can ask what is Local Government? There are avalanche of definitions given by various schools of thought about the concept. The Nigerian 1976 Local Government Reforms as enshrined in the 1979, 1989 and 1999 conditions of the Federal Republic of Nigeria defined Local Government as: "Government at the Local level ... established by law to exercise specific powers within defined areas (and) to initiate and direct provision of services and to determine and implement projects so as to complements the activities of the state and federal government in their area (Local Government Reforms, 1976). The United Nations Organization defines Local Governments 'As a political sub-division of a nation or in a federal system, a state which is constituted by law and has substantial control over the unit or local affairs including the power to impose taxes or to extract labour for prescribed purposes". In addition the International Encyclopaedia of social sciences (1976), defines Local Government as "A political sub-division of National or Regional Government which performs functions which nearly in all cases receive its legal power from the National regional government but possess some degree of discretion on the making of decisions and which normally has some taxing powers.

In Nigeria however, the functions and responsibilities of Local Government is contained in Fourth schedule of the 1999 constitutions of the Federal Republic of Nigeria and some of these functions that are of relevance to health services are as thus. Section 7(1) C specified the establishment and maintenance of cemeteries burial ground and homes for the destitute or infirm.

- Establishment, maintenance and regulation of slaughter houses, slaughter slabs, markets, motor parks and public conveniences; 
- Provision and maintenance of public conveniences, sewage and refuse disposal.

- Registration of all births, deaths.

- Control and regulation of movement and keeping of pets of all description, restaurants bakeries and other places of sale of food to the public.

The definitions above bring out four key characteristics of local government. First, local government officials are elected. Regular elections at specified period of time are a feature of local government. In fact, the main distinguishing characteristic that differentiates a local government from a local administration is the fact that while the officials of the former are elected those of the later are appointees of the centre to implement policies of the centre.

Second, the local government unit must have a legal personality distinct from the State and Federal Governments. Thirdly, the local government must have specified powers to perform a range of functions and finally, it must enjoy substantial autonomy. Local government autonomy means that the local government is elected at the local level and operate independently of the state and Federal Government. The local government is no longer an appendage or field office of the State government. The characteristics of local government autonomy include among other things ability to make its own laws, rules and regulations; formulate, execute and evaluate its own plans and the right to recruits, promote, develop and discipline its own staff.

Scholars and practitioners of local government over the years have been confronted with the question of the desirability or otherwise of local government. Various arguments have been advanced for the need for local government. It has been argued that local people will understand the problems confronting them more than other people and will be in better position to address the problems. $(\mathrm{Ola}, 1984)$ In addition, it is well established that people are prone to resisting impositions from above. Local government therefore provides opportunity for people to determine who should govern them at the local level. Finally, local government promotes personal liberty and participations of the people in governance. This is particularly important as it has been documented that participation by citizens is not only crucial for democracy and development but also that when citizens participate in the planning, execution, utilization and assessment of social amenities of facilities designed to improve their welfare, success of those efforts are assured (Onibokun and Faniran, 1995). Closely related to the above is the need to train people in the act of governance. It has been argued that local government serves as training ground for leaders who will subsequently move to State and federal levels. This is why local government has been described as "nurseries of democracy". This is particularly important in developing countries like Nigeria, which have been under long years of colonial and military rule with very limited experience in democratic governance.

\subsection{Local Government Reforms in Nigeria}

The history of Local Government system in Nigeria dates back to the colonial days. Although contact with Europeans dates back to the fifteenth century, it was not until 1861 before the first steps were taken to establish an administration by Britain. The colonial administration that was established was based on indirect rule. This requires that the administration should be carried out through traditional rulers and institutions. This led to the establishment of native authorities in their most rudimentary forms form the 1890s to the 1930s. The main function of the native authorities was to maintain law and other.

The first native authority ordinance recognized traditional rulers as native authorities. This was easily done in Northern Nigeria but there was a problem in identifying who those authorities were in southern Nigeria. This necessitated the first reforms in the 1930s and the 1940s culminating in the establishment of chief-in-council is made up to the chief and members of council. The chief presides at all meetings and acts in accordance with the majority of opinion in the council. But if he disagrees with the council, he would take whatever action the thought best and inform the Governor of the region. Contrarily, in the Chief-and-Council, the chief has no power to act against the decision or advice of the council. Under this arrangement, people particularly representatives of missionaries and British trading interest were appointed into the native authorities. The process of appointment of nominated members by the colonial government meant that nationalists were not appointed to serve on the councils. This led to further agitation for reforms in the native authorities. In the years 1950-55, the first largely elected local government council based on the British Whitehall model emerged in Lagos and the former Eastern and Western regions. Traditional rulers constituted not more than 25 percent of most council in the then western region and Lagos. However, in Northern Nigeria, the changes were more gradual. The legal framework for local government at this period was provided by the Eastern region local government ordinance of 1950, the Western region local government law of 1952 and the 1954 Native authority law in Northern Nigeria. By this time, the councils were given a wider range of functions including primary education, health, police, and judiciary. This is 
in line with the implementation of the colonial government's ten-year welfare and development plan (1945-1956). The councils also enjoyed a great measure of autonomy in financial, personnel and general administrative matters. It can therefore be said that the 1950s was the era of pupil age for councils in modern local government throughout Nigeria.

Between 1960 and 1966, there was a decline in the prestige and responsibilities of local authorities. In the former West region, the local government (Amendment) law 1960 abolished the powers of councils to levy education and general rates on the basis of need. In Lagos, there was high rate of default in the payment of property rate including government institution, which reduces the revenue of local councils. The situation in Eastern Nigeria was similar to the West before the outbreak of the civil war in 1967. In Northern Nigeria, there were gradual changes in the structure of the councils with increasing numbers of elected or appointed non-traditional office holders becoming members of local authorities. The result was that the local authorities had a stable administration, which enabled them to assume responsibility, with some degree of success for more complex services like primary education. Between 1969/71, some state government introduced some changes in the structure of their councils. In 1976, the Federal Government in collaboration with the state government embarked on extensive reforms of local government. The objectives of the reform were outlined as follows:

1. To make appropriate services and development activities responsive to local wishes and initiatives by devolving or delegating them to local representative bodies.

2. To facilitate the exercise of democratic self-government close to the grass roots of our society and to encourage initiative and leadership potential.

3. Mobilization of human material resources, through the involvement of members of the public in their local development, and

4. To provide a two-way channel of communication between local communities and government (both State and Federal).

For the first time in the history of local government in Nigeria, a uniform system was developed for whole country. According to the then Chief of Staff Brigadier Shehu M. Yar Adu-a in his forward to the Guidelines for Local Government Reform (1976):

In embarking on these reforms, the Federal Military Government was essentially motivated by the necessity to stabilized and rationalize Government was essentially motivated by the necessity to stabilize and rationalize Government at the local level. This must be necessity entail the decentralization of some significant functions of state governments to local levels in order to harness local resources for rapid development.

Unlike previous reform measures, which were highly restricted in scope and range, the 1976 reforms conceptualized local government as the third tier of government operating within a common institutional framework with defined function sand responsibilities. As the third tier of government, the local government gets statutory grants from Federal and state governments and is expected to serve as agent of development especially in rural areas. According to the 1976 reform, 75 percent of members of the council are to be elected through the secret ballot on a no-party basis under the direct and indirect systems of election. The remaining 25 percent are to be nominated by the State government. Following the reform, the Federal Government in 1977, allocated 5 percent of federally collected revenue to local government.

The intentions of the 1976 reform were debated by the constitution drafting committee and the Constituent assembly in 1978. The result is that the 1979 constitution reaffirmed the development function as provide for in section 7 , subsection 3.

It shall be the duty of a local government council within the state to participate in economic planning and development of the area referred to in subsection (2) of this section and to this end an economic planning board shall be established by a law enacted by the House of assembly of the State.

\section{Ofu local government area at a glance}

Ofu local government was initially located by the Shehu Shagari administration on $2^{\text {nd }}$ December 1980. It was however scraped by General Mohamadu Buhari's administration in 1983, but was again created on the 11 $1^{\text {th }}$ May, 1989 when the military government of president Ibrahim Babangida created six additional local governments in the then Benue State.

Ofu local government at creation had only three gazette districts. In June 1991 however, seven additional districts were created to bring the total number of district to ten. They include; Ugwulawo, Igalogba, itobe, Ojokogbe, Aloji, Ejule, Ogbonicha, Igo, Omache and Ofoke districts. The local government shares common boundries with Dekina local government to the north, Igalamela/Odolu local government to the south, Olamaboro to the south East and Ajaokuta to 
the west. It occupies a total land mass of about 8,747.5 square kilometers. The 2006 population census puts the local government's population figure at 192,169.

The people are predominantly engaged in Agriculture with a sizeable proportion engaged in government employment and business. The major agricultural activities are; fishing and the cultivation of crops like; maize, millet, rice, cassava etc.

\subsection{Local Government Performance in Ofu Local Government Area: A Situational Analysis}

How efficiently and efficiently again local governments are performing their duties and living up to their constitutional mandate has continued to be a huge source of concern to Nigerians, scholars, as were as practitioners of public administration.

A cursory look at Ofu local government area may give credence to the worries of most scholars and practitioners of public administration. The educational sector is in such a bad shape that pupils still sit under trees and on wood-logs to take lessons (when and where teachers are available). In the $21^{\text {st }}$ century, the few primary school building where available, are dilapidated and discouraging (Edicha, 2009).

Health care centers are mostly inhabitable grossly under staffed and without basic drugs. Ofu local government's laughable 18 poorly equipped/managed health centers, puts the ratio of health center to population at about 1:3000, which is totally unacceptable.

Besides, governmental processes and information retrieval is so slow and cumbersome in Ofu local government that action on some critical issues may be taken late, or not at all. (Edicha, 2009).

Table 3.1 below checks what Ofu local government has been doing with regards to capital project.

Table 3.1: Ofu Local Government's Capital Project 2009 - Feb 2011

\begin{tabular}{|c|c|c|c|c|}
\hline \multirow[t]{2}{*}{ Planned } & \multirow[t]{2}{*}{ District } & \multicolumn{3}{|c|}{ Level of implementation } \\
\hline & & Full & Partial & Not implemented \\
\hline $\begin{array}{l}\text { Grading of } 6 \text { rural federal roads } \\
\text { Rehabilitation of township } \\
\text { stadium } \\
\text { Purchasing of } 3 \text { graders } \\
\text { Rehabilitation of LG secretariat }\end{array}$ & Ugwolawo & $\begin{array}{l}\text { Rehabilitation } \\
\text { of LG } \\
\text { secretariat }\end{array}$ & $\begin{array}{l}\text { Purchase of } \\
\text { one grader }\end{array}$ & $\begin{array}{l}\text { Grading of } 6 \text { rural-feeder roads } \\
\text { Rehabilitation of township } \\
\text { stadium. }\end{array}$ \\
\hline $\begin{array}{l}\text { boreholes Rehabilitation of } 2 \\
\text { primary school }\end{array}$ & Itobe & - & - & All \\
\hline $\begin{array}{l}\text { Rehabilitation of } 3 \text { primary } \\
\text { schools supply Agro-inputs }\end{array}$ & Igalogba & - & - & All \\
\hline $\begin{array}{l}\text { Rehabilitation of } 2 \text { primary } \\
\text { school Rehabilitation of one } \\
\text { Health care centre }\end{array}$ & Ojokogbe & - & $\begin{array}{l}\text { Rehabilitation } \\
\text { of one primary } \\
\text { school }\end{array}$ & $\begin{array}{l}\text { Rehabilitation of one health care } \\
\text { centre }\end{array}$ \\
\hline $\begin{array}{l}\text { Rehabilitation of } 2 \text { health } \\
\text { centres grading of one road }\end{array}$ & Aloji & - & - & All \\
\hline $\begin{array}{l}2 \text { boreholes (Alla \& Agojeju) } \\
\text { Rehabilitation of } 3 \text { primary } \\
\text { schools }\end{array}$ & Ejule & - & - & All \\
\hline $\begin{array}{l}\text { Rehabilitation of } 2 \text { primary } \\
\text { school. Rehabilitation of one } \\
\text { boreholes }\end{array}$ & Ogbonicha & - & $\begin{array}{l}\text { Rehabilitation } \\
\text { of one primary } \\
\text { school }\end{array}$ & Rehabilitation of one borehole \\
\hline $\begin{array}{l}\text { Grading of two rural roads } \\
\text { Rehabilitation of health centre }\end{array}$ & $\lg 0$ & - & - & All \\
\hline $\begin{array}{l}\text { Development of Omache spring } \\
\text { building of } 2 \text { health centre }\end{array}$ & Omache & - & - & All \\
\hline $\begin{array}{l}\text { Rehabilitation of } 2 \text { primary } \\
\text { school Rehabilitation of } 1 \text { health } \\
\text { care centre }\end{array}$ & Ofoke & & $\begin{array}{l}\text { Rehabilitation } \\
\text { of one primary } \\
\text { school }\end{array}$ & $\begin{array}{l}\text { Rehabilitation of one health } \\
\text { centre }\end{array}$ \\
\hline
\end{tabular}

Source: Ofu Local Government Legislative Council (2010). 
The statistics on table 3.1 is a report of gross non-performance as well as it is every inch alarming. The only fully implemented capital project is the rehabilitation of the local government secretariat in Ugwolawo district, While four districts had partial implementation. The rest districts had no capital projects implemented (whether partially or fully). The local government's non-performance posture may be better appreciated when placed side-by-side, the financial resources at its disposal, as shown by Table 3.2 below.

Table 3.2: Quarterly Breakdown of Federal Allocation to Ofu Local Government

\begin{tabular}{|l|l|l|}
\hline Quarter & Source & Amount (N) \\
\hline \multirow{3}{*}{ January-April } & Statutory allocation & $200,684,623$ \\
\cline { 2 - 3 } & Vat & $18,312,431$ \\
\hline \multirow{3}{*}{ May-August } & Statutory allocation & $293,618,121$ \\
\cline { 2 - 3 } September-December & Vat & $21,111,293$ \\
\hline & Statutory allocation & $285,734,621$ \\
\cline { 2 - 3 } & Vat & $20,413,823$ \\
\cline { 2 - 3 } & Excess crude & $410,538,116$ \\
\hline Total & $\mathbf{1 , 2 5 0 , 4 1 3 , 0 2 8}$ \\
\hline
\end{tabular}

Source: Ofu local government legislative council (2011).

Ofu local government's performance with regards to capital projects is simply unacceptable especially that over N1.2 billion had entered its coffers within one calendar year. Besides, there is the need for a paradigm shift that equips the people to demand accountability from those who serve as custodians of public purse. Herein lays the efficacy of the egovernment initiative.

\section{Sample size and technique}

The total sample size for this study is made up of 61 respondents. This sample size was reached using judgment sampling technique. For the purpose of adequate representation of all variable under study, sample sizes were selected from each stratum thus: (I) Career Staff - 31 respondents, (ii) Stakeholders- 20 respondents (iii) Management Staff -6 respondents (iv) Political office holders- 4 respondents.

Each of this group of respondents was selected on the basis of their competence to speak on the subject matter of this research. Interviews were also conducted, especially to get the views of the political class and those of the people they lead. Besides, on the spot assessments of some of the projects was also conducted by way of personal observation.

\section{Presentation and analysis of data}

The questionnaire technique was majorly used for the gathering of data. At the end of the survey, analysis show, that amidst the 61 questionnaires administered, sixty one retrievals were made which is $100 \%$. This is indicative of how topical the issue under examination is, as well as how pressing the respondents took the opportunity to express their view and agitations for a better performance at the local level.

\subsection{Socio-Demographic Data of Respondents}

Table 5.1.1 Age composition of respondents

\begin{tabular}{|l|c|c|}
\hline Option & Number of Responses & Percentage (\%) \\
\hline Male & 42 & 68.85 \\
\hline Female & 19 & 32.14 \\
\hline
\end{tabular}

Source: field survey, 2011

The sex composition of respondents holds a lot of meaning for this study. 42 (68.85\%) are male, while 19 (32.14\%) are female. This readily indicates that there are more male employees, than their female counterparts. While this may be 
viewed as a lopsided composition, it may be a huge plus and potential for the local government and particularly egovernment. Giving the fact that a huge array of family duties and responsibilities jostles simultaneously for the African women's attention, it may be quite challenging for her to be actively involved in the learning of new administrative process and procedures like ICT in government. Hence, a sex composition that tilts in favour of men is of great potential for e-government in Ofu local government.

Table 5.1.2 Age composition of respondents

\begin{tabular}{|l|c|c|}
\hline Option & Number of respondents & Percentage (\%) \\
\hline 15-25years & 4 & 7.0 \\
\hline $26-36$ years & 46 & 75.41 \\
\hline $37-46$ & 6 & 10 \\
\hline $49-50$ years & 5 & 8.2 \\
\hline
\end{tabular}

Source: Field Survey ,2011

The table above gives a clear picture of the age bracket of the respondents. $15-25$ year bracket had $4(7 \%)$ respondents, 26-36 years had $46(75 \%)$ respondents, $37-466(10 \%)$ respondents while $47-57$ years had $5(8.2 \%)$. It is obvious from this data that the highest frequency of the ages are people between 26-36 years representing 75\% of the total respondents. This is follows by those of the age bracket of $37-46$, claiming $10 \%$ the total responses. This is every inch of huge asset to the local government as many young and energetic hearts and brains are in the local government and can be trained to enhance performance in Ofu local government.

Table 5.1.3 Educational Qualification of respondents

\begin{tabular}{|l|c|c|}
\hline Option & Number of respondents & Percentage (\%) \\
\hline FSLC & 4 & 4 \\
\hline SSCE & 6 & 9.8 \\
\hline ND/NCE & 31 & 50.8 \\
\hline BSC/BA/LLB/HND & 15 & 24.6 \\
\hline MSC/MA/LLM & 5 & 8.2 \\
\hline PhD & - & - \\
\hline
\end{tabular}

Source: field survey, 2011

Table 5.1.3 above show that 4 respondents (7\%) had primarily education as their highest educational qualification, 6 respondents (9.8\%) had secondary education as their highest educational qualification, 31 respondents (50.8\%) had diploma/NCE as their highest educations qualification, 15 respondents (24.6\%) had first degree highest education qualification, 5 respondents (8.2\%) had masters degree as their highest education qualification while non-had a PhD. It is important to note that these statistics hold a lot if implications for local government performance. With a workforce that has more people with Diplomas and first degrees, the local government should perform at least, creditably.

Table 5.1.4: Factors affecting Ofu Local Government's performance

\begin{tabular}{|l|c|c|}
\hline Options & Number of respondents & Percentage \\
\hline Lack of transparency and accountability & 15 & 24.6 \\
\hline Corruption & 21 & 34.4 \\
\hline Manual/slow administrative process & 10 & 16.4 \\
\hline Lack of funds & 1 & 1.6 \\
\hline Low employee morale & 8 & 13.1 \\
\hline All of the above & 7 & 11.4 \\
\hline
\end{tabular}

Source: Field Survey 2011 
Table 5.1.4 above show that $34.4 \%$ of respondents are of the opinion that the factor militating against the effective and efficient performance of Ofu Local Government is corruption. Indeed there are overwhelming evidence in Nigeria local government administration of how council officials cart away with funds meant for the local government. Hence Ukiwo (2006) is of the opinion that local government chairmanship has become one of the most attractive and lucrative positions in Nigeria.

Interviews with Ofu Local government stakeholders revealed that the local government has continued to suffer terrible financial haemorrhage because of the way local government funds are diverted into private pockets, with impurity. The consequence is that salaries are not paid for many months, capital/development projects are not embarked upon, leaving the local government, largely improvised.

$24.6 \%$ of the respondents blame Ofu local government's inefficient performance on the lack of transparency and accountability. Interviews further revealed that some vital information which are necessary to equip the people to hold government to accountability, are coved, a lot of the activities of the local governments are covered up in some kinds of secrecy, and since evil thrives in darkness, corruption reigns, making the local government unable to perform its constructional mandate and duty. Furthermore, $16.4 \%$ of respondents attribute Ofu local government's poor performance to its manual/analog administrative processes which slows down government response to public needs, and encourages a culture of rent seeking, bribery and corruption in its everyday activities. Similarly, $13.1 \%$ of respondents are of the opinion that low employee morale is responsible for Ofu local government's poor performance. This is supported by the fact that $82 \%$ of respondents earlier on rated Ofu local government very poor with regards to the payment of salaries and wages. Indeed, Ofu local government employees have had to endure in recent times, many month of non-payment of salaries. Expectedly, many of them are not motivated to come to work and to say their least, perform their duties effectively. This posture certainly takes its bad toll on local government performance. A negligible $1.6 \%$ is of the opinion that lack of funds may be responsible for local government poor performance. This very slim proportion may find an explanation in the fact that Ofu local government received a whooping \#1.2billion allocation from the federal government in 2010. This excludes internally generated and miscellaneous revenue. In sum, $11.4 \%$ of respondents are of the opinion that the lack of transparency and accountability, corruption, manual/analog administration practices, lack of funds and low employee morale are responsible for Ofu local government inefficient performance. Table 4.5.3 below however reveals a dimension to the challenges militating against the effective and efficient performance of Ofu local government that is very interesting.

It shows a wide gap between what the people need and want from government, as against what the government offers. This gap may hold very vial insights as to why Ofu local government is under performing.

\subsection{Corruption}

Table 5.1.4, indicates that the highest number of respondents (21) representing $34.4 \%$ are of the opinion that corruption is the major factor inhibiting Ofu local governments performance.

Table 5.1.5: Ofu local government's performance Rating (per of social services like road, school, water supply and security)

\begin{tabular}{|l|c|c|}
\hline Option & Number of respondents & Percentage (\%) \\
\hline Excellent & - & - \\
\hline Good & - & - \\
\hline Fair & 1 & 0.2 \\
\hline Poor & 4 & 7 \\
\hline Very poor & 56 & 92 \\
\hline
\end{tabular}

Field Survey 2011

Table 5.1.5 above indicates that Ofu local government has performed very poorly, with regarded to the provision of key social service like roads, schools, health care, among others. No respondent rate's the local government's perform as either excellent or good. One respondents (0.2\%) thinks the local government has performed fairly, four respondent (7\%) rates the local government as having performed poorly, but an incredible fifty six respondents (92\%) think the local government has perform very poorly. This position is perhaps reinforced by table 2.7.1, that earlier on indicated that 
between 2009 and February 2011 only one capital project was fully completed, while four, were partially completed. Six out of Ofu local governments ten district have not had a single capital project executed or being executed as at February 2011. These among others, led to a public outcry for which the council chairman was suspended for some months in 2010.

Table 5.1.6 Ofu local government's performance (per prompt and adequate payment of salaries and wages)

\begin{tabular}{|l|c|c|}
\hline Option & Number of respondents & Percentage (\%) \\
\hline Excellent & - & - \\
\hline Good & - & - \\
\hline Fair & 5 & 8.2 \\
\hline Poor & 6 & 9.8 \\
\hline Very poor & 82 & 92 \\
\hline
\end{tabular}

Field Survey, 2011

Table 4.5.2 above further explains the performance status of Ofu local government as 50 respondents $82 \%$ are of the opinion that the local government's performance per payments of salaries and wages of staff is very poor. Interviews with members of staff revealed that between September 2009 and January 2011 (with a few exceptions) Ofu local government employers were paid one quarter of their basic salaries, without allowances. It is not surprising therefore that only $8.2 \%$ and $9.8 \%$ of respondents rate the local government performance with regards to salaries and wages as fair and poor, respectively.

This rather disturbing statistics becomes even more mind bogging as the Ofu legislative council puts federal allocation to Ofu local government figures at about \#1.2 billion in 2010.

Table 5.1.7: Comparing the People's Needs with government intervention in Ofu local government.

\begin{tabular}{|c|c|c|}
\hline District & Government project programme & People expectation \\
\hline Ugwolawo & $\begin{array}{l}\text { a. Rehabilitation of LG secretariat } \\
\text { b. Internal security }\end{array}$ & $\begin{array}{l}\text { - Pipe born water } \\
\text { - Grading of Ugwolawo-Atoda road } \\
\text { - Maintenance/Rehabilitation of Ugwolawo market } \\
\text { - Grading of Ugwolawo-Ahi road }\end{array}$ \\
\hline Itobe & Nil & $\begin{array}{l}\text { Pipe born water } \\
\text { Cottage health centre/clinic in Itobe } \\
\text { Primary school building }\end{array}$ \\
\hline Igalogba & Internal security & $\begin{array}{l}\text { Grading of Okabo Alloma road } \\
\text { Pipe-born water }\end{array}$ \\
\hline Ojokogbe & Rehabilitation of one primary school & $\begin{array}{l}\text { Cottage health care centres } \\
\text { Construct more primary school } \\
\text { Agricultural inputs } \\
\text { Rehabilitation of markets }\end{array}$ \\
\hline Aloji & Nil & $\begin{array}{l}\text { Grading of Ojuwo-Omachi Ugwolawo road } \\
\text { Provision of agro inputs } \\
\text { Cottage }\end{array}$ \\
\hline Ejule & $\begin{array}{l}\text { Youth empowerment Scheme } \\
\text { Internal security }\end{array}$ & $\begin{array}{l}\text { Pipe born water } \\
\text { Grading of Ejule -Alla road } \\
\text { Grading of Ejule-Agojeju } \\
\text { Rehabilitation of Primary school. }\end{array}$ \\
\hline Ogbonicha & Rehabilitation of two primary school & $\begin{array}{l}\text { Boreholes for Ogbonicha } \\
\text { Ogbonicha central market }\end{array}$ \\
\hline Igo & Nil & Health care centres for Onisha-Igo and environs \\
\hline Omache & Youth empowerment scheme & $\begin{array}{l}\text { Development and packaging of Omache warm water spring } \\
\text { Rural feeder roads }\end{array}$ \\
\hline Ofoke & Rehabilitation of one primary school & $\begin{array}{l}\text { Agricultural input (fertilizers and pesticides } \\
\text { A cottage health care centre for Alo }\end{array}$ \\
\hline
\end{tabular}

Field Survey, 2011 
Table 5.1.7 above suggests a wide gap between the felt needs of the people and government interventions. This gap in communication and appropriate interventional may hold one of the critical answers to Ofu local government's below- the mark performance, and why it trails its counterpart in Kogi state, as it remains doubtful if any society can attain development if the needs of its people are at variance with government intervention

\section{Findings}

The major findings of this study are discussed below

(a) Ofu local government has performed very poorly with regards to the provision of key social services, payment of salaries and wages, speed and efficient among others. Tables 5.1.4, 5.1.5, and 5.1.6, suggest a very low performance profile on every indices under investigation.

(b) Ofu local government's performance does not in any way justify the huge financial resources that it has had access to from the federation account. Table 3.2 gives a breakdown of quarterly allocation of Ofu local government and leaves the total figure at about \#1.2billion. Ironically, table 2.7.1 reveals that only one capitals project was fully executed between 2009 and February 2011, while four projects in (Ugwolawo, Ojokogbe, Ogbonicha and Ofoke districts) are partially completed. Six out of Ofu local government's Ten districts had no single capital project executed to any extend or degree.

(c) Factors responsible for Ofu local governments poor performance are: corruption (34.4\%), lack of transparency and accountability (24.6\%), manual/slow administrative processes (16.4\%), low employee moral (13.1\%) and lack of funds which got the lowest support from respondents (1.6\%). $11.4 \%$ of the respondents however feel that not just one, but all these factors impede performance in Ofu local government.

Interestingly too, table 5.1.7 show that they exist a wide gap between the felt need of the people, and government interventions. Suggesting a critical communication gap between the two. This gap no doubt has deepened an already bad situation, as government continues to spend resources on concerns that in little or no way impacts on the quality of life of the people.

\section{Concluding Remarks}

Local governments in Nigeria have come a long way. Yet, the justification for their continued existence remains highly debatable, as there are overwhelming reasons to believe that the purpose for their existence is being defeated, especially with regards to efficient and effective performance. Be that as it may, it still remains the most popular form of decentralization; and with the renewed global support for more decentralization in public governance, the end of this third tier of government may not yet be in sight. To say the least, it has come to stay. It therefore behooves on the Nigerian government to think of more practical and sustainable ways, to reposition local governments to leave up to their responsibilities. It is therefore imperative to put structures in place to bridge the wide gap between government and the people, especially with regards to service delivery.

\section{Recommendations}

The following recommendations are made in the believe that they have the potentials to engender a positive turn-around in Ofu local government and indeed, the Nigeria local government system.

i) Agencies charged with oversight responsibilities on local governments like the Local Government Service Commission, the State Houses of Assembly etc should carry out periodic empirical studies on the performance of local government with the active participation of the people.

ii) The government should make the adoption of a freedom of information policy mandatory in all local governments. So that local government officials are compelled by law to make vital information, like income and expenditures public. This would equip the populace to demand accountability from the custodians of public wealth.

iii) Table 4.5.2 suggests a yawning gap between the actual needs of various communities, and government interventions. Local governments should employ ICT tools like radio and television (which is the most commonly used ICT in the rural areas) to harness the inputs of the people in the process of policy making

iv) Since wide spread corruption has become synonymous with local governments in Nigeria, a periodic audit of local governments should be carried out by a team of auditors selected by the federal, and state governments, 
as well as civil society organizations, to ensure a thorough audit that will not compromise, the standards of professionalism. This is because, when holders of public trust know that they could be held to accountability, the sense of impunity that facilitates corruption is put in check, making corruption less appealing.

\section{References}

Accenture (2004). "High Performance Government" http://www.accenture.com.

BBC news (2005a). "Fraud trial for Nigeria officials". http://news.bbc.co.uk

BBC news (2005b). "Nigerian's war against corruption". http://news.bbc.co.uk

BBC news (2005c). "Nigeria to get \$18bn debt relief" http://news.bbc.co.uk/1/hi/business

Blakemore, M. and Dutton, R. (2003)." e-Government, e-Society and Jordan: Strategy, theory, practice, and assessment" http://firstmonday.org/issues/issue8_11/blakemore/index.html

Blau, P. (1956). Bureaucracy in Modern Society, New York: Random House

Beetham, D. (1974.) Max Weber and the Theory of Modern Politics, London: Bettles press

Bellamy, C., and Taylor, J. (1998.) Information Age, Buckingham: Open University Press

Burns, T., and Stalker, G.M (1961). The Management of Innovation, London: Meline,.

CIA: World Factbook (2005). Country Report - Nigeria. http://www.cia.gov/.

Dutta, S., Lanvin, B. and Paua, F. (Eds.) (2003). Global Information Technology Report 2002-2003. Oxford: University press.

Edicha. K.(2009)."The Ofu of our dreams" A paper presented at the annual stakeholders conference of Ofu Development Association (ODA)

Ekpo, M.U. (1979) Bureaucratic Corruption in Subsaharan Africa, Washington, D.C: University Press of America

Idowu, O. W. (1999). "Citizenship status, statehood problems and political conflict: The case of Nigeria", Nordic

Journal of African Studies, 8, 2, 73-88.

Iheme, E. (2003). "The prohibition of Nigerian civil servants from political activities: A necessary derogation from freedom of association" The International Journal of Not-for-Profit Law, 6,http://www.icnl.org/JOURNAL/vol6iss1/.

Laski, H.J. (1953), "Bureaucracy," in: Ideas and Issues in PublicAdministration, D. Waldo (ed.), New York: McGraw-Hill, pp. 36-41.

Merton, R.K (1957). Social Theory and Social Structure, Glencoe :FreePress

Ofu Local Government Legislative Council (2011)"The facts you must know" Legislative Hall mark( 4) 2 3-4

Ogwumike, O. F. (2002). "An appraisal of poverty reduction strategies in Nigeria". CBN Economic and Financial Review, 39, 4, 1-17.

Rossel, R.D.(1979) "Autonomy in Bureaucracies.,"Administrative Science Quarterly (16:3) pp 308-315.

Selznick, P. (1949)TVA and the Grass Roots. Berkeley: UniversityOf California Press.

Transparency International Corruption Perceptions Index [TICP] (2003). http://www.transparency.org

Turaki,I.S.(2004)."eGovernance:TheJigawaexperience"http://news.biafranigeriaworld.com/archaive

United Nations Economic Commission for Africa [UNECA ](2004). "National Information and Communication Infrastructure: Policies and Plans (e-strategies)" UNECA,http://www.uneca.org/aisi/nici/nici

United Nation University Press (2004) "Growth of information technology [Nigeria] " http: //www .unu. edu/ unupress / unupbooks/uu19ie/uu19ie0e.htm.

World Bank Group (2004). "Reports on Nigeria" http:// www.worldbank.org 
